\title{
COMPLEMENTARY IMPACT OF CAPABILITIES AND BRAND ORIENTATION ON SMBS PERFORMANCE
}

\section{Anita CIUNOVA-SHULESKA ${ }^{1}$, Christian Nedu OSAKWE ${ }^{2}$, Nikolina PALAMIDOVSKA-STERJADOVSKA ${ }^{3}$}

\author{
${ }^{1,3}$ Faculty of Economics, Ss.Cyril and Methodius University, Skopje, Republic of Macedonia \\ ${ }^{2}$ Faculty of Management and Economics, Tomas Bata University in Zlin, Czech Republic \\ E-mails: 1anita@eccf.ukim.edu.mk (corresponding author); \\ 2osakwe@fame.utb.cz; ${ }^{3}$ nikolina@eccf.ukim.edu.mk
}

Received 14 July 2015; accepted 18 April 2016

\begin{abstract}
The purpose of this study is to analyse the interrelationships among capabilities and brand orientation and their effect on performance of the small and medium-sized businesses. A data set of 181 effective responses is collected and Partial Least Squares was used. The main drivers of customer performance are brand orientation and adaptive and brand promotional capabilities, while financial performance is determined by brand promotional and e-marketing capabilities and by customer performance. Brand orientation directly influences adaptive and brand promotional capabilities, while e-marketing capability is positively influenced by brand promotional capability. SMBs operating in the developing economy context need to combine multiple capabilities and brand orientation with focus on building e-marketing capability to improve financial performance. This research study is one of the first in the South-eastern European context to offer evidencebased insights on the structural relations among multiple capabilities, brand orientation and the performance of SMBs.
\end{abstract}

Keywords: adaptive capability, brand promotional capability, e-marketing capability, brand orientation, customer performance, financial performance.

JEL Classification: L25, M30.

\section{Introduction}

The question of capabilities-performance relationship and competitiveness occupies a central place in the management literature. Resource-based view (RBV) and dynamic capabilities-based view center attention on idiosyncratic organizational resources and capabilities as determining factors of business competitiveness. Moreover, market competition forces companies to face the challenge of improving their competitiveness by finding more efficient management processes and orientations and by improving their competences.

While acknowledging the fact that existing studies have made fruitful attempts at exploring a firm's capabilities vis-à-vis performance, especially in the case of larger en- 
terprises and in western economies (Abraham et al. 2001; Barney 1995), a similar story cannot be stated in the context of SMBs that are situated outside the OECD, especially those in the South-eastern European economies. Also, empirical studies about brand management in small and medium-sized businesses (SMBs) are limited and have focused almost exclusively on large companies in developed economies.

Inarguably, SMBs contribute much more to wealth creation opportunities than multinational companies and/or indigenous large-scale businesses (European Commission 2013). In a transition European economy such as the Republic of Macedonia, SMBs account for nearly 100 percent of the active number of business enterprises (State Statistical Office of RM 2012). However, large and SMBs differ in terms of management style, operations, and functions (Knight 2000). The findings of Berthon et al. (2008) indicated that small and large companies significantly differ along most of the brand management dimensions and follow different brand management practices. Moreover, Kumar et al. (2012) claimed that strategic orientations differ across companies with different size. According to Krake (2005) SMBs can take an advantage from investing into brand building activities by building passion for the brand. Also, given the nature and characteristics of SMBs, marketing management competencies of SMBs must either be different or at least have different emphasis and priority within an SMB (Carson, Gilmor 2000).

Therefore, researching the relationships among brand orientation, capabilities and performance of the SMBs is a challenging task. Additional contribution of this study is that it involves and examines e-marketing capability contributing to the limited knowledge of its effect on business performance and its relationship with promotional and adaptive capabilities. Moreover, the analyses of adaptive capability in SMBs and its effect on performance is an area of study in its infancy (Feifei 2012). Also, there are limited studies that investigate the complementary impact of strategic orientation and capabilities on performance (Sinkovics, Roath 2004; Morgan et al. 2009).

Responding to the call by Harrison-Walker (2014) for further investigation of the consequences of brand orientation and to the call by Trainor et al. (2014) for investigation of the relationship between firm resources and marketing practices, this study undertakes to bridge the research gap by developing and testing an integrated research model by analysing the complementary contribution of three types of competencies and brand orientation to SMBs performance in a developing economy within the European context. Moreover, this research study is one of the first in the South-eastern European context to offer evidence-based insights on the structural relations among multiple capabilities, brand orientation and the performance of SMBs.

With the dynamic capabilities-based view serving as the primary conceptual lens, literature from marketing and brand management is used to develop our integrated model of the three firm-specific capabilities along with its antecedent (brand orientation) and outcomes (customer loyalty and financial performance).

The three main research questions our work seeks to address are: 1) What is the nature and magnitude of the interrelationships among some of the stated capabilities and brand 
orientation? 2) What are the effects of some of the highlighted capabilities and brand orientation on the business performance? 3) Can a significant positive-direct link be established between customer and financial performance of the SMBs?

In the next section, we present a review of the theoretical background of the study with the hypotheses following suit. Further, we presented the results of the study in the ensuing section following the research methods. Thereafter, we present an overview of the research findings with research implications. The limitations of the study, future research and concluding remarks are presented in the separate sections in the end of the manuscript.

\section{Literature review and derivation of hypotheses}

Companies differ in their performance as a consequence of differences in the way how they deploy the resources they possess (Song et al. 2008). RBV assumes that the resources and capabilities a company possesses can create competitive advantage on the market and consequently can lead to a superior performance (Barney 1995). If a company wants to outperform competitors, it is not enough just to possess superior resources, but it must have superior and distinctive capabilities and knowledge how to deploy its scare resources to create a competitive advantage.

Dynamic capability perspective as an extension of the RBV emphasizes the role of capabilities in the attempts of the company to meet the environmental changes (Helfat, Peteraf 2009).

Brand promotional, adaptive and e-marketing capabilities represent critical issues for firms operating in turbulent settings in emerging economies and especially to SMBs which are more inclined to use e-marketing channels for responding to competitors and providing enhanced customer services (Daniel, Grimshow 2002), and possess higher flexibility in adjusting to market changes.

Adaptive capability refers to a firm's ability to reconfigure resources and coordinate processes to respond to rapid environmental changes ( $\mathrm{Lu}$ et al. 2010).

Important preconditions for market success closely related to adaptive capability are brand management capabilities, i.e. "the firm's ability to create and sustain reputational assets such as brand equity and corporate image" (Foley et al. 2007: 275), as well as the capability to utilize Internet technology in marketing communication activities (e-marketing capability). This study views e-marketing capability as a company's competency in utilizing e-marketing channels in business operation. Regarding brand-promotional capability, the focus of this study is on capability of a company to communicate brand values to the customers, by managing promotional activities. The conceptual logic that capabilities are positively associated with performance (Teece 2014) is based on the recognition that capabilities encompass skills and knowledge that have been acquired in the past practices of the organization (Theodosiou et al. 2012). According to Foley et al. (2007) brand capabilities affect firm's performance. The study of Luxton et al. (2015) confirmed that integrated communication capability directly influences brand 
market performance and indirectly brand's financial performance. Moreover, the ability to coordinate activities in order to reinforce the brand's position and ensure effective execution of brand promotional programs is essential for reinforcing the brand's meaning (Beverland et al. 2007), which results in increased customer satisfaction and financial performance (Orr et al. 2011).

According to Kwon and Lennon (2009) prior offline brand image of a multichannel company significantly influences online brand beliefs. Therefore, we assume that companies with higher level of brand promotional capability will demonstrate higher level of e-marketing capability.

Given that the need to adapt the brand's image, positioning, and supportive marketing programs on market changes is vital for brand success, companies should build capabilities that allow adaptation and implementation of innovative solutions by reinforcing brand identity (Beverland et al. 2007). Furthermore, brand success is driven by continuously building consistent brand image and reputation in a changing environment i.e. ensuring brand updating capability (Yakimova, Beverland 2005). Consequently, the following hypotheses are derived:

H1: Brand promotional capability has positive effect on customer performance.

H2: Brand promotional capability has positive effect on financial performance.

H3: Brand promotional capability has positive effect on e-marketing capability.

H4: Brand promotional capability has positive effect on adaptive capability.

Wei and Lau (2010) and Hofer et al. (2015) found empirical evidence that firms with high adaptive capability perform at a higher level than firms with low adaptive capability.

Beverland et al. (2007) claimed that adaptability to key customers and markets and constant marketing innovation are main drivers of brand success. Internal resources and capabilities are antecedents of e-marketing penetration and adoption (Brodie et al. 2007), and consequently of e-marketing capability. Accordingly, it is proposed here that:

H5: Adaptive capability has positive effect on customer performance.

H6: Adaptive capability has positive effect on financial performance.

H7: Adaptive capability has positive effect on e-marketing capability.

Krasnikov and Jayachandran (2008) found that marketing capability has stronger positive impact on firm performance than the impact of research-and-development and operations capabilities. A positive relationship between marketing capabilities and firm performance was also found by Ngo and O'Cass (2012). Brodie et al. (2007) confirmed that the adoption of e-marketing is positively associated with marketing performance (acquisition and retention performance). Trainor et al. (2014) found that e-marketing capabilities have a positive influence on customer relationship performance and financial performance, while Tsiotsou and Vlachopoulou (2011) confirmed the direct effect on productivity, service quality and net profit. Accordingly, it is proposed here that: 
H8: e-marketing capability has positive effect on customer performance.

H9: e-marketing capability has positive effect on financial performance.

Harrison-Walker (2014) found that brand orientation has a positive impact on the company's use of integrated marketing communications, on the development of a unique brand position, on the distinctiveness of the brand, and on the continuous efforts toward brand development and innovation. Brand orientation in this study is viewed as "an approach in which the processes of an organization revolve around the creation, development and protection of brand identity in an ongoing interaction with target customers with the aim of achieving lasting competitive advantages in the form of brands" (Urde 1999: 117).

Zhou and Li (2010) confirmed that strategic orientations can facilitate firms' capability to adapt to the changing environment. Since different strategic orientations lead to different configuration and reconfiguration of company's resources (Zhou, Li 2010) which enable the firm to adapt to the market changes in terms of responding to the current and emerging customer needs (Atuahene-Gima, Ko 2001), we assume that brand orientation positively influence company's capability to cope with competitive environments, i.e. adaptive capability. Furthermore, Wong and Merrilees (2008) and Laukkanen et al. (2013) proved the positive relationship between brand orientation and brand (customer) performance. Consequently, the following hypotheses are derived:

H10: Brand orientation has a positive effect on brand promotional capability.

H11: Brand orientation has a positive effect on adaptive capability.

H12: Brand orientation has a positive effect on customer performance.

Wong and Merrilees (2008) and Santos-Vijande et al. (2013), confirmed the significant and positive relationship between customer performance and financial performance. Similarly, Luxton et al. (2015) confirmed positive relationship between brand market and brand financial performance. Consequently, the following hypothesis is proposed:

H13: Customer performance has positive effect on financial performance.

\section{Research methods}

\subsection{Sampling procedure and sample characteristics}

The object of analysis is a profit-oriented enterprise with staff strength of 1-249 employees, i.e., SMB. Non-probabilistic sampling procedure, i.e., referral sampling technique was used in the research. The research study was performed from October 2014 to December 2014 in the Republic of Macedonia. A total of 500 structured questionnaires were distributed among SMBs in the country through referrals from our key informants. The effective response rate was about 36.2 percent, that is, 181 of the returned 191 questionnaires were deemed to be suitable and consequently used in the final data analysis. The demographic characteristics of the sample are presented in Table 1. 
Table 1. Summary statistics of the sample

\begin{tabular}{lc}
\hline \multicolumn{1}{c}{ Sample characteristics } & Frequency (\%) \\
\hline \multicolumn{1}{c}{ Position } \\
\hline Owner & 37 \\
\hline Manager & 63 \\
\hline Age of organization & 34.3 \\
\hline 1-6 years & 65.7 \\
\hline More than 6 years & \\
\hline \multicolumn{2}{c}{ Number of employees } \\
\hline $1-9$ employees & 21.4 \\
\hline 10-49 employees & 21.5 \\
\hline $50-249$ employees & 6.6 \\
\hline \multicolumn{2}{c}{ Type of business sector } \\
\hline Financial sector & 6.6 \\
\hline Tourism and hospitality & 7.7 \\
\hline Food industry & 2.8 \\
\hline Textile industry & 17.1 \\
\hline Telecommunication & 34.8 \\
\hline Consulting (accounting, marketing, law etc.) & 6.1 \\
\hline Trading & 3.3 \\
\hline Transport/warehousing/logistic & 15 \\
\hline Other &
\end{tabular}

\subsection{Measurements}

All the measurement scales used in the study, particularly those that were adapted from the extant literature were originally in English but were first translated into the Macedonian language and later back-translated into English by bilingual experts in the business fields. All the constructs are reflective and were measured on a five-point Likert scale ranging from "1 - Strongly Disagree" to "5 - Strongly Agree" with the exception of one construct (i.e., eMk) that ranges from " 0 - Not At All" to "4 - Large Extent".

The adaptive capability construct was operationalized using three items. Two of these items were adapted from prior research (You et al. 2013) while one item (ADC3) was originated from the authors based on an extensive literature review. The brand promotional capability construct (three items) and e-marketing capability construct (five items) were self-developed for this study. The four-item brand orientation scale was adapted from the works of Wong and Merrilees (2008) and Laukkanen et al. (2013). The customer performance construct consisted of five-items and it was adapted from the study of Voola et al. (2012), as well as the financial performance construct which consisted of four-items. Items of the survey instrument can be seen in Appendix A. All the constructs have high level of internal consistency, suggested by the values of Cronbach's alpha coefficients ranging from 0.70 to 0.94 , which are in line with the commonly reported baseline values in the empirical literature (Hair et al. 2011). 


\subsection{Analytical procedure}

Due to the relatively small sample size, as well as to the complexity of the research model and its exploratory nature, PLS-SEM was adopted as a method of data analysis. Prior to testing the study's hypotheses, the common method variance (CMV) was checked and the result of the unrotated one-factor solution (Harman's single factor test) indicates that the most dominant factor could only account for about 33 percent of the total cumulative variance in the sample dataset. This suggests that CMV might not after all be an issue of any major concern within the framework of this study. To a large extent, we believe that the key informants in the study are well-informed of their companies' activities and importantly that the information they have provided is likely to be devoid of any "major" form of bias since they were not obliged to act as participants in the study. More importantly, the sample size in the study exceeds the 10-times rule (in relation to the number of latent variables).

\section{Results}

\subsection{Evaluation of the measurement model}

All the standardized indicator loadings are statistically significant $(p<0.001)$ and most of them are at least 0.8 . As a further check for construct reliability, we used the measure of composite reliability (CR) with values ranging from 0.84 to 0.89 for the constructs in the research model (see Table 2).

Table 2. Indicator loadings, construct reliability with convergent validity

\begin{tabular}{lllll}
\hline Constructs/Items & Loadings & T Stats & CR & AVE \\
\hline ADC & & & 0.928 & 0.812 \\
\hline ADC1 & 0.888 & 38.722 & & \\
\hline ADC2 & 0.939 & 98.673 & & \\
\hline ADC3 & 0.875 & 27.324 & & 0.759 \\
\hline BO & & & 0.926 & \\
\hline BO1 & 0.871 & 35.228 & & \\
\hline BO2 & 0.884 & 40.503 & & \\
\hline BO3 & 0.890 & 31.051 & & \\
\hline BO4 & 0.839 & 20.606 & & \\
\hline BPC & & & 0.838 & \\
\hline BP1 & 0.883 & 35.370 & & \\
\hline BP2 & 0.873 & 31.491 & & \\
\hline BP3 & 0.612 & 7.774 & & \\
\hline FPF & & & 0.950 & \\
\hline FPF1 & 0.897 & 45.570 & & \\
\hline FPF2 & 0.923 & 75.890 & & \\
\hline FPF3 & 0.912 & 63.731 & & \\
\hline
\end{tabular}


End of Table 2

\begin{tabular}{lcccc}
\hline Constructs/Items & Loadings & T Stats & CR & AVE \\
\hline FPF4 & 0.905 & 54.423 & & \\
\hline CPF & & & 0.954 & 0.805 \\
\hline CPF1 & 0.903 & 47.023 & & \\
\hline CPF2 & 0.894 & 43.396 & & \\
\hline CPF3 & 0.879 & 39.715 & & \\
\hline CPF4 & 0.907 & 52.859 & & 0.765 \\
\hline CPF5 & 0.903 & 47.544 & & \\
\hline Emk & & & 0.942 & \\
\hline eMK4 & 0.843 & 11.921 & & \\
\hline eMK1 & 0.859 & 13.676 & & \\
\hline eMK2 & 0.899 & 14.448 & & \\
\hline eMK3 & 0.895 & 14.776 & & \\
\hline eMK5 & 0.876 & 13.456 & & \\
\hline
\end{tabular}

Source: Authors' calculations.

We further examined the construct validity in a much more rigorous manner as espoused by Fornell and Larcker (1981). In terms of convergent validity, the reported average variance extracted (AVE) of every construct in the model is in the range of 0.64 to 0.83 (see Table 2). Pertaining to the discriminant validity of the constructs, the square roots of the AVEs exceeded the inter-correlation coefficients of the constructs (see Table 3).

Table 3. Discriminant validity of research constructs

\begin{tabular}{lllllll}
\hline & BPC & BO & ADC & CPF & eMK & FPF \\
\hline BPC & 0.80 & & & & & \\
\hline BO & 0.60 & 0.87 & & & & \\
\hline ADC & 0.31 & 0.39 & 0.90 & & & \\
\hline CPF & 0.40 & 0.41 & 0.42 & 0.90 & & \\
\hline eMK & 0.13 & 0.07 & 0.06 & 0.11 & 0.87 & \\
\hline FPF & 0.36 & 0.40 & 0.33 & 0.54 & 0.19 & 0.91 \\
\hline
\end{tabular}

Note: Square roots of AVEs in the diagonal cells (italicized and bold fonts).

Source: Authors' calculations.

\subsection{Evaluation of the structural model with tests of hypotheses}

The proposed research model was evaluated based on commonly reported statistical measures (see Table 4) and statistical significance of predictor variables (Hair et al. 2011; Henseler et al. 2009). The t-values were estimated based on bootstrapping results (5000 subsamples). The R2 values suggest that nearly 36 percent of the variation in BPC is explained within the model while 28 percent and 34 percent of the variations in $\mathrm{CPF}$ 
and FPF are respectively explained. The Q2 values of all the endogenous constructs in the model are all on the positive sides, thus, further suggesting that the research model as a whole has a "high" predictive relevance. Importantly, all the path coefficients of the exogenous constructs in the model have the hypothesized signs, although four out of the thirteen hypothesized relationships in the research model were found to be statistically insignificant ( $p>0.1$ ) based on a two-tailed test (see Table 4). Additionally, the coefficients between a control variable (company size) and each dependent variable were more or less insignificant, indicating that hypothesized relationships are not influenced by the company size. By running a post-hoc test (Bonferroni test in ANOVA) marginal difference was found only between companies with 1 to 9 and those with a minimum of 50 employees regarding eMK.

A pictorial diagram of the SmartPLS output showing relevant information can be seen in Appendix B. In terms of practical significance of the predictor variables (i.e., using the Cohen's $f^{2}$ index) and using the formula as described in Henseler et al. (2009); we were able to compute and report the findings of the effect sizes of nearly all the exogenous constructs in the model (see Table 5).

Table 4. Results of the structural model and hypotheses validation

\begin{tabular}{|c|c|c|c|c|c|c|c|}
\hline \multirow{2}{*}{ Relations } & \multicolumn{2}{|l|}{ Path coefficients } & \multirow{2}{*}{ S. Error } & \multirow{2}{*}{ T-Stats. } & \multirow{2}{*}{ Hypothesis } & \multirow{2}{*}{$\mathrm{R}^{2}$} & \multirow{2}{*}{$\mathrm{Q}^{2}$} \\
\hline & Original sample & Sample mean & & & & & \\
\hline $\mathrm{ADC} \rightarrow \mathrm{CPF}$ & 0.288 & 0.289 & 0.075 & $3.830 * *$ & $\mathrm{~S}$ & & \\
\hline $\mathrm{ADC} \rightarrow \mathrm{FPF}$ & 0.101 & 0.106 & 0.063 & 1.612 & NS & & \\
\hline $\mathrm{ADC} \rightarrow \mathrm{eMK}$ & 0.019 & 0.074 & 0.054 & 0.352 & NS & & \\
\hline $\mathrm{BO} \rightarrow \mathrm{ADC}$ & 0.315 & 0.317 & 0.095 & $3.319^{* *}$ & $\mathrm{~S}$ & & \\
\hline $\mathrm{BO} \rightarrow \mathrm{BPC}$ & 0.596 & 0.601 & 0.044 & $13.693 * *$ & $\mathrm{~S}$ & & \\
\hline $\mathrm{BO} \rightarrow \mathrm{CPF}$ & 0.186 & 0.190 & 0.093 & $1.994 *$ & $S$ & & \\
\hline $\mathrm{BPC} \rightarrow \mathrm{ADC}$ & 0.126 & 0.134 & 0.080 & 1.584 & NS & & \\
\hline $\mathrm{BPC} \rightarrow \mathrm{CPF}$ & 0.187 & 0.185 & 0.086 & $2.174 *$ & $\mathrm{~S}$ & & \\
\hline $\mathrm{BPC} \rightarrow \mathrm{FPF}$ & 0.145 & 0.150 & 0.072 & 2.023 & $\mathrm{~S}$ & & \\
\hline $\mathrm{BPC} \rightarrow \mathrm{eMK}$ & 0.128 & 0.137 & 0.075 & $1.715^{+}$ & $\mathrm{S}$ & & \\
\hline $\mathrm{CPF} \rightarrow \mathrm{FPF}$ & 0.429 & 0.428 & 0.085 & $5.042 * *$ & S & & \\
\hline $\mathrm{eMK} \rightarrow \mathrm{CPF}$ & 0.054 & 0.076 & 0.051 & 1.042 & NS & & \\
\hline $\mathrm{eMK} \rightarrow \mathrm{FPF}$ & 0.113 & 0.118 & 0.057 & $1.999^{*}$ & $\mathrm{~S}$ & & \\
\hline
\end{tabular}

Sub-models

\begin{tabular}{lll}
\hline ADC & 0.163 & 0.123 \\
\hline BPC & 0.355 & 0.231 \\
\hline CPF & 0.278 & 0.230 \\
\hline eMK & 0.018 & 0.013 \\
\hline FPF & 0.339 & 0.281 \\
\hline
\end{tabular}

Note: ${ }^{* *} \mathrm{p}<0.01 ;{ }^{*} \mathrm{p}<0.05 ;{ }^{+} \mathrm{p}<0.1$. Source: Authors' calculations. 
Table 5. Effect size (Cohen's $f^{2}$ index) of predictor variables in the model

\begin{tabular}{lll}
\hline Target construct & Predictor variable & Cohen's $f^{2}$ index \\
\hline FPF & ADC & 0.01 \\
\hline FPF & BPC & $0.03^{+}$ \\
\hline FPF & CPF & $0.20^{*}$ \\
\hline FPF & eMK & $0.02^{+}$ \\
\hline CPF & ADC & $0.10^{*}$ \\
\hline CPF & BO & $0.03^{+}$ \\
\hline CPF & BPC & $0.03^{+}$ \\
\hline CPF & eMK & Null \\
\hline ADC & BO & $0.07^{+}$ \\
\hline
\end{tabular}

Note: ${ }^{* *}$ strong effect $-0.35 ; *$ moderate effect $-0.15 ;{ }^{+}$weak effect -0.02 (Cohen 1988). Source: Authors' calculations.

\section{Conclusions and discussion}

Pertaining to theoretical contributions, this study fills the research gaps, concerning the lack of simultaneous analysis of capabilities and brand orientation on performance especially in SMBs settings. Furthermore, the novelty of this research lies in its inclusion of adaptive and e-marketing capabilities, in investigation of the relationship between e-marketing capability and performance, and between e-marketing capability, and adaptive and brand promotional capabilities in the SMBs context. In addition, this paper has a pivotal role in investigating the proposed relationships in South-eastern European setting.

Our results confirmed the brand promotional capability-financial performance relationship, brand promotional capability-customer performance relationship and brand promotional e-marketing capability relationship. Surprisingly, no empirical evidence was found for the relationship between brand promotional and adaptive capabilities. This might be explained by the notion that well-known brands are less vulnerable to the competitive marketing actions and crises; that possessing strong brands creates less concern about the need for adjusting on the market or it can be explained by the influence of the context. Furthermore, brand orientation is a direct antecedent to brand promotional and adaptive capabilities, implying that companies can build brands more effectively in the long run by implementing brand orientation. Also, brand orientation and adaptive capability are strong determinants of customer performance, whereas adaptive capability has no direct influence on both e-marketing capability and financial performance. While e-marketing capability is a strong determinant of financial performance, and has no influence on customer performance, significant direct relationship was found between customer and financial performance. 


\section{Managerial and theoretical implications}

Regarding business/managerial practice, the results of this study may help managers in at least five ways. First, SMBs' managers should focus on developing adaptive, brand building and e-marketing capabilities, but should be cautious in investing their scarce resources in building adaptive and e-marketing capabilities as tools for increasing financial performance. Notwithstanding, adaptive capability is a direct determinant of customer performance, suggesting that it is a useful capability that SMBs should benefit from. Second, as expected the results indicate that e-marketing capability is a pivotal determinant of financial performance but it is not of customer performance. This result might even be suggestive that utilization of e-marketing channel is a good alternative in terms of costs savings for the SMBs. On the other hand, we could not establish empirical evidence on the relationship between e-marketing capability and customer performance, suggesting that SMBs may not after all perceive the utilization of the Internet as an appropriate channel for building long-term customer relationships. Third, SMBs' managers should invest in building brand promotional capabilities since they are antecedents of customer performance, financial performance and e-marketing capabilities. Our findings further revealed that brand promotional capability has a positive but negligible effect on adaptive capability. Fourth, this study has highlighted the role of brand orientation as a useful strategy for SMBs that positively contributes to adaptive capability, brand promotional capability and customer performance. Fifth, customer performance is a significant antecedent to subjective financial performance, indicating that the SMBs should be focused on building strong customer loyalty along with keeping loyal customers satisfied. Altogether, the findings of the study strengthen existing literature that are at the interface of brand management, dynamic capability of the firm and the emerging subject area of e-marketing as our results are indicative that the mix of adaptive, brand promotional and e-marketing capabilities and brand orientation is a fundamental tool for fostering the performance of SMBs.

\section{Study limitations and future research}

Despite the revealing outcomes of the research model, this study is a subject of several limitations. First, the use of referral sampling technique significantly limits our ability to make broader generalizations from our results. Another limitation of this study is the research on a single country. Also, engaging in cross-country studies in order to see the applicability of a model in different country settings may be a challenging task. This study deals with a multiple industry setting, thus, it would be interesting for future studies to focus on a particular industry. In order to improve predictive accuracy of the model, other intervening variables might come into play. More so, future studies should consider measuring performance using objective measures to increase the validity of the results. Finally, future studies should explore the mediating role of brand promotional, adaptive and e-marketing capabilities in specific capability-performance relationships.

\section{Acknowledgements}

One of the authors is deeply indebted to the Internal Grant Agency of FaME TBU (No. IGA/FAME/2015/039) for support of this work. 


\section{References}

Abraham, S. E.; Karns, L. A.; Shaw, K.; Mena, M. A. 2001. Managerial competencies and the managerial performance appraisal process, Journal of Management Development 20(10): 842852. http://dx.doi.org/10.1108/02621710110410842

Atuahene-Gima. K.; Ko, A. 2001. An empirical investigation of the effect of market orientation and entrepreneurship orientation alignment on product innovation, Organization Science 12(1): 54-73. http://doi.dx.org/10.1287/orsc.12.1.54.10121

Barney, J. B. 1995. Looking inside for competitive advantage, The Academy of Management Executive 9(4): 49-61. http://doi.dx.org/10.5465/AME.1995.9512032192

Berthon, P.; Ewing, M. T.; Napoli, J. 2008. Brand management in small to medium-sized enterprises, Journal of Small Business Management 46(1): 27-45.

http://doi.dx.org/10.1016/S0969-5931(00)00006-8

Beverland, M.; Napoli, J.; Lindgreen, A. 2007. Industrial global brand leadership: a capabilities view, Industrial Marketing Management 36(8): 1082-1093.

http://doi.dx.org/10.1016/j.indmarman.2006.08.007

Brodie, R. J.; Winklhofer, H.; Coviello, N. E.; Johnston, W. 2007. Is e-marketing coming of age? An examination of the penetration of e-marketing and firm performance, Journal of Interactive Marketing 21(1): 2-21. http://doi.dx.org/10.1002/dir.20071

Carson, D.; Gilmor, A. 2000. SME marketing management competencies, International Business Review 9: 363-382. http://dx.doi.org/10.1016/S0969-5931(00)00006-8

Cohen, J. 1988. Statistical power analysis for the behavioral sciences. New Jersey: Lawrence Erlbaum Associates.

Daniel, E. M.; Grimshaw, D. J. 2002. An exploratory comparison of electronic commerce adoption in large and small enterprises, Journal of Information Technology 17(3): 133-147.

http://dpi.dx.org/10.1080/0268396022000018409

European Commission. 2013. A recovery on the horizon? Annual report on European SMEs 2012/2013, Final report [online], [cited 4 May 2015]. Available from Internet: http://ec.europa. eu/enterprise/policies/sme/facts-figures-analysis/performance-review/files/supporting-documents/2013/annual-report-smes-2013_en.pdf

Feifei, Y. U. 2012. Strategic flexibility, entrepreneurial orientation and firm performance: evidence from small and medium-sized business (SMB) in China, African Journal of Business Management 6(4): 1711-1720. http://doi.dx/org/10.5897/AJBM11.1910

Foley, L.; Bush, V.; Vorhies, D. 2007. Internal and externally-focused marketing capabilities and firm performance, AMA Winter Educators' Conference Proceedings 18: 275-276.

Fornell, C.; Larcker, D. F. 1981. Evaluating structural equation models with unobserved variables and measurement error, Journal of Marketing Research 18(1): 39-50.

http://doi.dx.org/10.2307/3151312

Hair, J. F.; Ringle, C. M.; Sarstedt, M. 2011. PLS-SEM: indeed a silver bullet, Journal of Marketing Theory and Practice 19(2): 139-152. http://doi.dx.org/10.2753/MTP1069-6679190202

Harrison-Walker, L. J. 2014. Manifestations of a strategic brand orientation, Academy of Marketing Studies Journal 18(1): 203-216.

Helfat, C.; Peteraf, M. 2009. Understanding dynamic capabilities: progress along a developmental path, Strategic Organization 7(1): 91-102. http://doi.dx.org/10.1177/1476127008100133

Henseler, J.; Ringle, C. M.; Sinkovics, R. R. 2009. The use of partial least squares path modeling in international marketing, Advances in International Marketing 20: 277-319.

http://doi.dx.org/10.1108/S1474-7979(2009)0000020014 
Hofer, K. M.; Niehoff, L. M.; Wuehrer, G. A. 2015. The effects of dynamic capabilities on valuebased pricing and export performance, Advances in International Marketing 25: 109-127. http://dx.doi.org/10.1108/S1474-797920140000025005

Knight, G. A. 2000. Entrepreneurship and marketing strategy: the SME under globalization, Journal of International Marketing 8(2): 12-32. http://dx.doi.org/10.1509/jimk.8.2.12.19620

Krake, F. 2005. Successful brand management in SMEs: a new theory and practical hints, Journal of Product \& Brand Management 14(4): 228-238. http://dx.doi.org/10.1108/10610420510609230

Krasnikov, A.; Jayachandran, S. 2008. The relative impact of marketing, research-and-development, and operations capabilities on firm performance, Journal of Marketing 72: 1-11.

http://doi.dx.org/10.1509/jmkg.72.4.1

Kumar, K.; Boesso, G.; Favotto, F.; Menini, A. 2012. Strategic orientation, innovation patterns and performances of SMEs and large companies, Journal of Small Business and Enterprise Development 19(1): 132-145. http://doi.dx.org/10.1108/14626001211196442

Kwon, W. S.; Lennon, S. J. 2009. Reciprocal effects between multichannel retailers' offline and online brand images, Journal of Retailing 85(3): 376-390.

http://doi.dx.org/10.1016/j.jretai.2009.05.011

Laukkanen, T.; Nagy, G.; Hirvonen, S.; Reijonen, H.; Pasanen, M. 2013. The effect of strategic orientations on business performance in SMEs: a multigroup analysis comparing Hungary and Finland, International Marketing Review 30(6): 510-535.

http://doi.dx.org/10.1108/IMR-09-2011-0230

Lu, Y.; Zhou, L.; Bruton, G.; Weiwen, L. 2010. Capabilities as a mediator linking resources and the international performance of entrepreneurial firms in an emerging economy, Journal of International Business Studies 41: 419-436. http://doi.dx.org/10.1057/jibs.2009.73

Luxton, S.; Reid, M.; Mavondo, F. 2015. Integrated marketing communication capability and brand performance, Journal of Advertising 44(1): 37-46.

http://doi.dx.org/10.1080/00913367.2014.934938

Morgan, N. A.; Vorhies, D. W.; Mason, C. H. 2009. Market orientation, marketing capabilities, and firm performance, Strategic Management Journal 30(8): 909-920.

http://doi.dx.org/10.1002/smj.764

Ngo, L. V.; O’Cass, A. 2012. Performance implications of market orientation, marketing resources, and marketing capabilities, Journal of Marketing Management 28(1-2): 173-187.

http://doi.dx.org/10.1080/0267257X.2011.621443

Orr, L. M.; Bush, V. D.; Vorhies, D. W. 2011. Leveraging firm-level marketing capabilities with marketing employee development, Journal of Business Research 64: 1074-1081.

http://doi.dx.org/10.1016/j.jbusres.2010.11.003

Santos-Vijande, M. L.; del Río-Lanza, A. B.; Suárez-Álvarez, L.; Díaz-Martín, A. M. 2013. The brand management system and service firm competitiveness, Journal of Business Research 66(2): 148-157. http://doi.dox.org/10.1016/j.jbusres.2012.07.007

Sinkovics, R. R.; Roath, A. S. 2004. Strategic orientation, capabilities, and performance in manufacturer-3PL relationships, Journal of business Logistics 25(2): 43-64.

http://doi.dox.org/10.1002/j.2158-1592.2004.tb00181.x

Song, M.; Nason, R. W.; Di Benedetto, C. A. 2008. Distinctive marketing and information technology capabilities and strategic types: a cross-national investigation, Journal of International Marketing 16(1): 4-38. http://dx.doi.org/10.1509/jimk.16.1.4

State Statistical Office of RM. 2012. Structural business statistics [online], [cited 12 April 2015]. Available from Internet: http://www.stat.gov.mk/OblastOpsto_en.aspx?id=39 
Teece, D. J. 2014. A dynamic capabilities-based entrepreneurial theory of the multinational enterprise, Journal of International Business Studies 45(1): 8-37.

http://doi.dopx.org/10.1057/jibs.2013.54

Theodosiou, M.; Kehagias, J.; Katsikea, E. 2012. Strategic orientations, marketing capabilities and firm performance: an empirical investigation in the context of frontline managers in service organizations, Industrial Marketing Management 41(7): 1058-1070.

http://doi.dox.org/10.1016/j.indmarman.2012.01.001

Trainor, K. J.; Andzulis, J.; Rapp, A.; Agnihotri, R. 2014. Social media technology usage and customer relationship performance: a capabilities-based examination of social CRM, Journal of Business Research 67: 1201-1208. http://doi.dx.org/10.1016/j.jbusres.2013.05.002

Tsiotsou, H. R.; Vlachopoulou, M. 2011. Understanding the effects of market orientation and emarketing on service performance, Marketing Intelligence \& Planning 29(2): 141-155.

http://doi.dx.org/10.1108/02634501111117593

Urde, M. 1999. Brand orientation: a mindset for building brands into strategic resources, Journal of Marketing Management 15: 117-133. http://doi.dx.org/10.1362/026725799784870504

Voola, R.; Casimir, G.; Carlson, J.; Agnihotri, M. A. 2012. The effects of market orientation, technological opportunism, and e-business adoption on performance: a moderated mediation analysis, Australasian Marketing Journal 20: 136-146. http://doi.dx.org/10.1016/j.ausmj.2011.10.001

Wei, L.-Q.; Lau, C.-M. 2010. High Performance work systems and performance: the role of adaptive capability, Human Relations 63(10): 1487-1511. http://doi.dx.org/10.1177/0018726709359720

Wong, H. Y.; Merrilees, B. 2008. The performance benefits of being brand oriented, Journal of Product \& Brand Management 17(6): 372-383. http://doi.dx.org/10.1108/10610420810904112

Yakimova, R.; Beverland, M. 2005. The brand-supportive firm: an exploration of organisational drivers of brand updating, Journal of Brand Management 12(6): 445-460.

http://dx.doi.org/10.1057/palgrave.bm.2540239

You, C.; Zhang, J.; Xi, L.; Wenwen, A. 2013. How market-guanxi ambidexterity affects adaptive vapability in China's transition economy, Frontiers of Business Research in China 7(4): 461-486. http://doi.dx.org/10.3868/s070-002-013-0020-7

Zhou, Z. K.; Li, B. C. 2010. How strategic orientations influence the building of dynamic capability in emerging economies, Journal of Business Research 63(3): 224-231.

http://doi.dx.org/10.1016/j.jbusres.2009.03.003 


\section{APPENDIX A}

\section{Items as reflected in the survey instrument}

ADC1 - We are capable of reacting properly to changes in the market.

ADC2 - Our existing competency can withstand changes in the industry.

ADC3 - We have the existing competency needed to withstand challenges brought about by external environment crises/shocks.

BO1 - Building a brand name is a focal part of our business strategy.

$\mathrm{BO} 2$ - Building a brand is integrated in all our marketing.

$\mathrm{BO} 3$ - Brand is a value asset to our company.

BO4 - Building a brand is important for our business operations.

BPC1 - We usually set aside some amount of money for advertising our products/services.

BPC2 - We have a marketing budget that we use effectively for company's promotional activities.

BPC3 - We are able to manage all our company's contact points (e.g. advertising, logo, customer dialogues, website, product/service) to convey the same values/messages to our customers.

CPF1 - The levels of customer loyalty in our organization look to be increasing on a yearly basis.

CPF2 - Within the last two years, our company has been quite successful at retaining most of our existing/new customers.

CPF3 - The levels of customer satisfaction compared to previous years have significantly increase.

CPF4 - We have more loyal customers than most of our direct competitors.

CPF5 - Compared to previous years, our customers are now much happier with our services/products.

FPF1 - Relative to our direct competitors, our profit levels have significantly increased in the last two years.

FPF2 - Within the last two years, our profit margins have significantly improve.

FPF3 - In the last two years, we have become more satisfied with our company's financial position.

FPF4 - Our return on investment has significantly improve in the last two years.

eMK1 - We use electronic marketing channel(s) to engage/collaborate with our existing customers/prospects.

eMK2 - We use e-marketing channel(s) to promote our brand image.

eMK3 - We use e-marketing channel(s) to communicate what our company's unique offerings from the rest of the competition.

eMK4 - We use e-marketing channel(s) to develop our marketing intelligence.

eMK5 - We use e-marketing channel(s) to offer solutions/suggestions to customers' needs. 


\section{APPENDIX B}

\section{Pictorial diagram of the model's SmartPLS output}

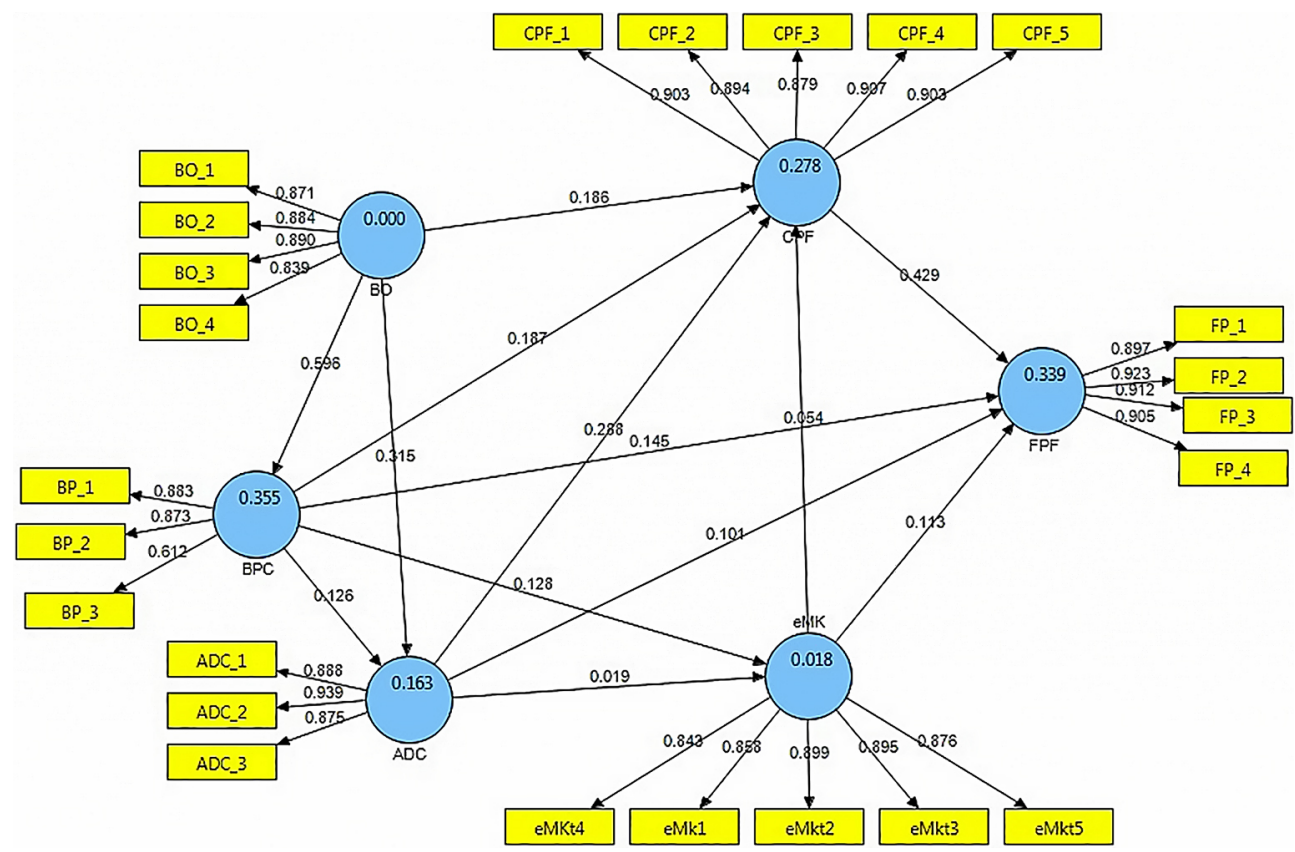

Anita CIUNOVA-SHULESKA. PhD, Faculty of Economics-Skopje, Ss. Cyril and Methodius University in Skopje, Macedonia. Main research interests: consumer attitudes and behaviour, customer satisfaction, marketing strategies.

Christian Nedu OSAKWE. PhD Candidate, Tomas Bata University in Zlin, Czech Republic. Main research interests: applied marketing research, e(m) Commerce, micro, small and medium-sized enterprises (MSMEs), and strategic marketing.

Nikolina PALAMIDOVSKA-STERJADOVSKA. PhD, Faculty of Economics-Skopje, Ss. Cyril and Methodius University in Skopje, Macedonia. Main research interests: customer satisfaction, service quality, consumer behaviour and marketing strategies. 